\title{
Cryptococcus gattii
}

National Cancer Institute

\section{Source}

National Cancer Institute. Cryptococcus gattii. NCI Thesaurus. Code C114268.

An encapsulated yeast in the phylum Basidiomycota. This species is globose to ovoid shaped, urease-positive, pseudohyphae- and nitrate-neg ative, does not ferment sug ars, and assimilates glucose, maltose, sucrose, galactose, trehalose, raffinose, inositol, cellobiose, rhamnose, arabinose, melezitose and xylose. C. gattii is a human opportunistic pathogen and causes pulmonary cryptococcosis, basal mening itis and cerebral cryptococcomas in immunocompromised hosts. It is also associated with skin, soft tissue, lymph node, bone, and joint infections. 